\title{
Penampilan dan Kualitas Telur Puyuh yang Diberi Pakan Mengandung Produk Fermentasi dengan Neurospora crassa
}

\section{Performances and Quail Egg Quality Feeding Product Fermented with Neurospora crassa}

\author{
Nuraini, Sabrina dan S. A Latif
}

Fakultas Peternakan Universitas Andalas

Kampus Unand Limau Manis Padang, 25163

e-mail: nani_nuraini0505@yahoo.com

(Diterima: 21 April 2011; Disetujui: 3 Juli 2011)

\begin{abstract}
An experiment was conducted to determine the effect of feeding products fermented by Neurospora crassa on quail performances and egg quality. 200 quail layers were randomly allocated into 20 pens. This experiment was arranged in a completely randomized design (CRD) with four dietary treatments: $0 \%, 3 \%, 6 \%, 9 \%$ and $12 \%$ product fermented by Neurospora crassa in the diets and four replications. Variable measured were feed comsumption, egg production, feed conversion, egg cholesterol and egg yolk colour. Data were analized by CRD and Duncan Multiple Range Test (DMRT). Results of the experiment indicated that feed comsumption, egg production, feed conversion were not affected $(P>0.05)$ but egg cholesterol and egg yolk colour were affected $(P<0.01)$ by using product fermented in the diets for quails. Results of Duncant Multiple Range Test indicated that egg cholesterol in E treatment (used $12 \%$ products fermented) was the lowest than other treatment, but the highest on egg yolk colour. The conclusion of the experiment that up to $12 \%$ products fermented by Neurospora crassa can be used in the diet of quail and can increase the quality of quail egg (egg low cholesterol).
\end{abstract}

Keywords: product fermented, Neurospora crassa, layer performances, egg quality

\section{PENDAHULUAN}

Pakan fermentasi kaya $\beta$ karoten dapat dibuat dengan menggunakan substrat asal limbah agroindustri seperti ampas sagu dan ampas tahu, yang difermentasi dengan menggunakan Neurospora crassa. Kapang Neurospora crassa yang berwarna kuning orange merupakan kapang penghasil $\beta$ karoten tertinggi dibandingkan dengan kapang karotenogenik lainnya yang telah diisolasi dari tongkol jagung (Nuraini dan Marlida, 2005).

Kandungan zat - zat makanan campuran $60 \%$ ampas sagu dan $40 \%$ ampas tahu sebelum fermentasi adalah protein kasar $12,67 \%$, lemak kasar 2,59\%, serat kasar $18,36 \%$, dan $\beta$-karoten $30,60 \mathrm{mg} / \mathrm{kg}$, dan setelah difermentasi dengan $9 \%$ inokulum Neurospora crassa dan diinkubasi selama 7 hari, diperoleh kandungan dan kualitas nutrien produk fermentasi adalah $\beta$-karoten
$270,60 \mathrm{mg} / \mathrm{kg}$, protein kasar 21,78\%, lemak $2,50 \%$, serat kasar $16,23 \%$, kalsium $0,44 \%$, fospor $0,02 \%$, energi metabolis 2980 $\mathrm{kkal} / \mathrm{kg}$, retensi nitrogen $62,91 \%$ dan kecernaan serat kasar 30,23\%. Ditinjau dari segi kandungan protein terjadi peningkatan terhadap protein kasar dan $\beta$ karoten serta penurunan terhadap serat kasar produk fermentasi dengan Neurospora crassa.

Penggunaan produk pakan fermentasi yang kaya $\beta$ karoten dalam ransum unggas selain dapat menggantikan penggunaan jagung juga dapat menghasilkan telur yang rendah kolesterol. Hasil penelitian Nuraini (2006) menunjukkan bahwa pemberian produk fermentasi kaya $\beta$ karoten yang diperoleh dari campuran ampas sagu dan ampas tahu yang difermentasi dengan Neurospora crassa (ASATF) dapat mengurangi penggunaan jagung $50 \%$ dan dapat menurunkan kolesterol telur ayam sebanyak $35 \%$. 
Penggunaan produk fermentasi kaya $\beta$ karoten terhadap ternak puyuh belum diketahui, oleh karena itu perlu dipelajari penggunaan produk fermentasi kaya $\beta$ karoten dalam ransum puyuh dengan tujuan untuk mengetahui berapa batasan penggunaan produk fermentasi dengan Neurospora crassa dalam ransum puyuh dan bagaimana pengaruhnya terhadap penam pilan dan kualitas telur (kolesterol dan warna kuning telur) puyuh.

\section{METODE}

Penelitian dilakukan selama 2 bulan menggunakan puyuh petelur sebanyak 200 ekor strain Coturnix Coturnix Japonica yang berumur 4 minggu. Setiap unit perlakuan masing - masing berisi 10 ekor puyuh. Ransum disusun sendiri dari bahan-bahan seperti jagung, bungkil kedelai, tepung ikan, produk ampas sagu dan ampas tahu fermentasi dengan Neurospora crassa (ASATF) dan tepung CaCO3. Pembuatan produk ASATF dengan cara ampas sagu sebanyak $60 \%$ dicampur dengan $40 \%$ ampas tahu kemudian ditambahkan aquades (kadar air 70\%), diaduk secara merata, baru dikukus selama 30 menit setelah air mendidih untuk sterilisasi bahan, setelah itu dibiarkan sampai tercapai suhu kamar. Substrat kemudian diinokulasi dengan 9\% inokulum kapang Neurospora crassa, diaduk secara merata dan diinkubasi selama 7 hari. Setelah itu produk fermentasi dipanen, dikeringkan dengan menggunakan sinar matahari dan digiling (Nuraini, 2006). Ampas sagu diperoleh dari tempat pembuatan tepung sagu dan ampas tahu berasal dari pabrik tahu di Padang, dikumpulkan dalam keadaan segar, kemudian dikeringkan. Rancangan yang digunakan adalah Rancangan Acak Lengkap (RAL) dengan 5 perlakuan dan 4 kali ulangan. Perlakuan adalah ransum yang menggunakan produk campuran ampas sagu dan ampas tahu fermentasi (ASATF) yaitu ransum A (0\% ASATF), B (3\% ASATF), C (6\% ASATF), D (9\% ASATF) dan E(12\%
ASATF). Data dianalisis dengan menggunakan analisis keragaman pola RAL dan perbedaaan antar perlakuan diuji dengan Duncan Multiple Range Test (DMRT) menurut Steel and Torrie (1980). Ransum disusun isoprotein $(22 \%)$ dan isokalori (2900 kkal/kg) berdasarkan SNI (2006). Pemberian ransum dilakukan 3 kali sehari yaitu pagi (jam 8.00 WIB), siang (jam 12.00 WIB), sore (jam 16.00 WIB) sedangkan air minum diberikan ad libitum. Komposisi dan kandungan nutrien ransum perlakuan tercantum di Tabel 1.

Peubah yang diamati adalah: 1) konsumsi ransum (g/ekor/hari) diukur dengan cara mengurangi jumlah ransum yang diberikan dengan sisa ransum. Konsumsi ransum diukur satu kali seminggu, 2) produksi telur harian/ quail day production (\%), dihitung berdasarkan jumlah telur yang diproduksi pada waktu tertentu dibagi dengan jumlah puyuh yang ada pada waktu tersebut, 3) bobot telur ratarata (g/butir), diperoleh dengan membagi bobot telur total kemudian dibagi dengan jumlah telur selama penelitian, 4) produksi massa telur (g/ekor/hari), diperoleh dengan cara quail day selama satu bulan dikalikan bobot rata - rata sebutir telur yang dihasilkan dalam bulan tersebut, 5) konversi ransum dihitung dengan cara membagi konsumsi ransum (g/ekor/hari) dengan produksi massa telur (g/ekor/hari), 6) Kualitas telur meliputi: a) kolesterol telur $(\mathrm{mg} / 100 \mathrm{~g})$ dengan menggunakan spectrofotometer UV, b) warna kuning telur: diukur dengan menggunakan Roche Egg Yolk Colour Fan.

\section{HASIL DAN PEMBAHASAN}

Rataan performans puyuh petelur disajikan pada Tabel 2. Pemberian produk fermentasi kaya $\beta$ karoten dalam ransum puyuh tidak nyata $(\mathrm{P}>0.05)$ mempengaruhi konsumsi ransum, produksi telur (quail day production), berat telur, masssa telur dan konversi ransum, tetapi sangat nyata 0.01 ) mempengaruhi kolesterol telur dan warna kuning telur puyuh. 
Tabel 1. Komposisi dan kandungan zat -zat makanan ransum perlakuan $\left({ }^{\mathrm{a}}\right)$

\begin{tabular}{|c|c|c|c|c|c|}
\hline \multirow{2}{*}{ Bahan pakan } & \multicolumn{5}{|c|}{ Ransum Perlakuan (\%) } \\
\hline & RA & $\mathrm{RB}$ & $\mathrm{RC}$ & $\mathrm{RD}$ & $\mathrm{RE}$ \\
\hline Jagung Giling & 48,00 & 46,00 & 44,00 & 42,00 & 40,00 \\
\hline Dedak padi Halus & 8,00 & 8,00 & 8,00 & 7,00 & 7,00 \\
\hline Bungkil Kedelai & 16,00 & 15,00 & 14,00 & 14,00 & 13,00 \\
\hline ASATF & 0,00 & 3,00 & 6,00 & 9,00 & 12,00 \\
\hline Tepung Ikan & 19,00 & 19,00 & 19,00 & 19,00 & 19,00 \\
\hline Minyak Kelapa & 3,00 & 3,00 & 3,00 & 3,00 & 3,50 \\
\hline Tepung batu & 6,00 & 6,00 & 6,00 & 6,00 & 6,00 \\
\hline Total & 100,00 & 100,00 & 100,00 & 100,00 & 100,00 \\
\hline \multicolumn{6}{|l|}{$\begin{array}{l}\text { Kandungan zat- zat } \\
\text { makanan }(\%)^{\text {b) }}\end{array}$} \\
\hline Protein Kasar & 22,17 & 22,09 & 22,02 & 22,05 & 22,13 \\
\hline Lemak & 5,57 & 5,56 & 5,54 & 5,52 & 5,52 \\
\hline Serat Kasar & 3,58 & 3,92 & 4,26 & 4,52 & 4,86 \\
\hline Kalsium & 2,40 & 2,40 & 2,40 & 2,39 & 2,38 \\
\hline Fosfor tersedia & 0,52 & 0,51 & 0,51 & 0,50 & 0,50 \\
\hline $\begin{array}{l}\text { Energi Metabolis } \\
(\mathrm{kkal} / \mathrm{kg})\end{array}$ & 2903,00 & 2903,00 & 2904,00 & 2907,00 & 2908,00 \\
\hline Metionin (\%) & 0,40 & 0,40 & 0,40 & 0,40 & 0,40 \\
\hline Lisin $(\%)$ & 1,17 & 1,17 & 1,17 & 1,17 & 1,17 \\
\hline$\beta$-karoten & 24,79 & 32,05 & 39,31 & 46,58 & 53,48 \\
\hline
\end{tabular}

Sumber: (a) Hasil analisis laboratorium Teknologi \& Industri Pakan, Fakultas Peternakan, Universitas Andalas Padang, 2009

(b) Berdasarkan perhitungan

ASATF $=$ Ampas Sagu Ampas Tahu Fermentasi

Tabel 2. Pengaruh Perlakuan terhadap Performa Ayam dan Kualitas Telur.

\begin{tabular}{|c|c|c|c|c|c|c|}
\hline \multirow{2}{*}{ Performa } & \multicolumn{5}{|c|}{ Ransum Perlakuan (\% ASATF dalam ransum) } & \multirow[b]{2}{*}{ SE } \\
\hline & $\begin{array}{l}\mathrm{RA} \\
(0 \%)\end{array}$ & $\begin{array}{c}\mathrm{RB} \\
(3 \%) \\
\end{array}$ & $\begin{array}{c}\mathrm{RC} \\
(6 \%) \\
\end{array}$ & $\begin{array}{l}\mathrm{RD} \\
(9 \%)\end{array}$ & $\begin{array}{c}\mathrm{RE} \\
(12 \%)\end{array}$ & \\
\hline $\begin{array}{ll}\begin{array}{l}\text { Konsumsi } \\
\text { (g/ekor/hari) }\end{array} & \text { Ransum } \\
\end{array}$ & 19,89 & 19,92 & 19,94 & 20,24 & 20,33 & 0,24 \\
\hline Quail day (\%) & 72,99 & 73,79 & 73,06 & 74,22 & 74,25 & 2,06 \\
\hline Berat telur (g/butir) & 9,94 & 10,07 & 10,07 & 10,20 & 10,29 & 0,30 \\
\hline $\begin{array}{l}\text { Massa Telur } \\
\text { (g/ekor/hari) }\end{array}$ & 6,85 & 6,97 & 6,90 & 7,08 & 7,20 & 0,41 \\
\hline Konversi Ransum & 2,90 & 2,86 & 2,88 & 2,85 & 2,82 & 0,09 \\
\hline Warna Kuning Telur & $9,00^{\mathrm{C}}$ & $9,50^{\mathrm{C}}$ & $10,25^{\mathrm{B}}$ & $10,75^{\mathrm{B}}$ & $11,50^{\mathrm{A}}$ & 1,03 \\
\hline $\begin{array}{l}\text { Kolesterol telur } \\
(\mathrm{mg} / 100 \mathrm{~g})\end{array}$ & $264,75^{\mathrm{A}}$ & $244,25^{\mathrm{A}}$ & $213,00^{\mathrm{B}}$ & $182,00^{\mathrm{C}}$ & $158,50^{\mathrm{C}}$ & 3,73 \\
\hline
\end{tabular}

Keterangan: Superskrip huruf kapital yang berbeda pada baris yang sama menunjukkan berbeda sangat nyata $(\mathrm{p}<0.01)$ 


\section{Konsumsi Ransum}

Tidak berbeda nyatanya konsumsi ransum antara perlakuan yang menggunakan $12 \%$ produk fermentasi yaitu 20,93 g/ekor/hari dengan perlakuan lainnya, berkaitan dengan palatabilitas ransum yang sama pada setiap perlakuan. Ini berarti produk ampas sagu dan ampas tahu fermentasi disukai puyuh petelur (palatabel) sampai level $12 \%$ dalam ransum, walaupun semakin berkurang penggunaan jagung dan konsentrat dalam ransum tersebut. Kemampuan produk ASATF sebagai pakan alternatif yang dapat mengimbangi pengurangan penggunaan jagung dan konsentrat dalam ransum, disebabkan produk fermentasi mempunyai flavour yang lebih disukai dan memiliki beberapa vitamin $\left(\mathrm{B}_{1}, \mathrm{~B}_{2}\right.$ dan $\left.\mathrm{B}_{12}\right)$ sehingga lebih palatabel (disukai) bila dibandingkan bahan asalnya. Selain itu pada fermentasi terjadi proses - proses pemecahan oleh enzim - enzim tertentu terhadap zat -zat makanan yang sulit dicerna, sehingga daya cerna bahan yang telah difermentasi meningkat dibandingkan bahan asal (Murugesan et al., 2005).

\section{Produksi Telur}

Pemberian ASATF sampai level 12\% dalam ransum memperlihatkan produksi quail-day production $(74,25 \%)$ yang tidak berbeda dengan ransum kontrol, ini disebabkan konsumsi ransum yang sama mengakibatkan konsumsi protein yang diperlukan untuk produksi telur juga tidak berbeda. Konsumsi protein pada perlakuan $12 \%$ ASATF adalah 4,49 g/ekor/hari, sedangkan pada perlakuan $0 \%$ ASATF diperoleh konsumsi protein sebesar 4,40 g/ekor/hari. Produksi quail day yang sama pada perlakuan $12 \%$ ASATF berkaitan dengan kandungan asam amino esensial lisin, metionin dan triptophan dalam ransum yang hampir sama (Tabel 1). Ini menunjukkan bahwa kandungan asam amino yang terdapat pada jagung dan bungkil kedelai pada perlakuan kontrol dapat diimbangi oleh asam amino yang yang dihasilkan oleh Neurospora crassa selama fermentasi pada substrat ampas sagu dan ampas tahu (Tabel 3) walaupun telah terjadi pengurangan penggunaan jagung dan bungkil kedelai dalam ransum. Kapang Neurospora crassa dapat menghasilkan asam amino metionin dan arginin (Marathe et al., 1998) dan tirosin (Lerch, 1978).

\section{Berat Telur}

Hasil uji statistik menunjukkan bahwa pemberian ASATF juga tidak nyata mempengaruhi berat telur ayam. Pada pemberian ASATF sampai $12 \%$ dalam ransum puyuh memperlihatkan berat telur yang tidak berbeda dibandingkan perlakuan lainnya, seiring dengan samanya konsumsi ransum dan konsumsi protein pada perlakuan tersebut. Menurut Keshavarz (2003) bahwa konsumsi ransum terutama konsumsi protein akan mempengaruhi berat telur yang dihasilkan. Berat telur yang tidak berbeda pada perlakuan dengan pemberian $12 \%$ ASATF dengan perlakuan lainnya juga dipengaruhi oleh kandungan metionin dalam ransum dan konsumsi ransum yang sama pada perlakuan $12 \%$ ASATF sehingga konsumsi metionin juga sama. Metionin merupakan asam amino esensial kritis yang sangat berpengaruh terhadap bobot telur (Safaa, 2008 dan Kashavarz, 2003). Bobot telur yang diperoleh dengan penggunaan $12 \%$ ASATF adalah 10,29 $\mathrm{g} /$ butir, hasil penelitian ini tidak jauh beda dengan yang diperoleh Soares et al., (2003) yaitu 9-10 g/butir dengan kandungan protein $22 \%$ dan konsumsi protein 5,00 g/ekor/hari.

\section{Massa Telur}

Massa telur juga tidak nyata dipengaruhi oleh perlakuan pemberian ASATF dalam ransum. Semakin banyak diberikan ASATF (12\% dalam ransum) . 
Tabel 3. Kandungan asam amino sebelum dan sesudah fermentasi

\begin{tabular}{lcc}
\hline Asam Amino & $\begin{array}{c}\text { Ampas sagu + Ampas tahu } \\
\text { sebelum fermentasi } \\
(\%)\end{array}$ & $\begin{array}{c}\text { Ampas sagu +Ampas Tahu } \\
(60 \%: 40 \%) \\
\text { sesudah fermentasi }\end{array}$ \\
\hline Alanin & 0,32 & 0,76 \\
Arginin & 0,60 & 1,05 \\
Asparagin & 0,88 & 1,25 \\
Glycin & 0,68 & 0,65 \\
Glutamin & 2,15 & 2,75 \\
Histidin & 0,21 & 0,30 \\
Isoleusin & 0,33 & 0,52 \\
Leusin & 0,83 & 1,06 \\
Lisin & 0,20 & 1,38 \\
Methionin & 0,10 & 0,12 \\
Phenilalanin & 0,49 & 0,65 \\
Valin & 0,65 & 0,72 \\
Prolin & 0,53 & 0,72 \\
Treonin & 0,40 & 0,50 \\
Serin & 0,35 & 0,64 \\
Cystein & 0,10 & 0,20 \\
Tyrosin & 0,33 & 0,52 \\
Tryptophan & 0,03 & 0,13 \\
\hline Sum : & Tasil & 2007
\end{tabular}

Sumber : Hasil analisis Laboratorium Makanan Ternak, Fakultas Peternakan, IPB Bogor, 2007

memperlihatkan massa telur yang tidak berbeda nyata dibandingkan perlakuan lainnya. Ini disebabkan produksi telur dan berat telur juga sama pada perlakuan $12 \%$ ASATF karena massa telur merupakan hasil kali produksi telur dan berat telur. Massa telur yang diperoleh berkisar dari 6,857,20 g/ekor/hari, hasil ini termasuk dalam range yang didapatkan Sathishkumar dan Prabakaran (2008) bahwa produksi massa telur puyuh umur 5-9 minggu sebanyak 7 10 g/ekor/hari.

\section{Konversi Ransum}

Pada Tabel 2 dapat dilihat bahwa puyuh yang mendapat ransum mengandung ASATF sampai level $12 \%$ sama efisiennya dalam memanfaatkan ransum sehingga mampu memproduksi telur dengan konversi ransum yang sama dengan ransum kontrol. Hal ini menunjukkan bahwa puyuh sama efisiennya dalam memanfaatkan ransum yang semakin banyak menggunakan ASATF walaupun mengakibatkan semakin banyak pula terjadi pengurangan jagung dan bungkil kedelai dalam ransum.

\section{Kolesterol Telur}

Ditinjau dari segi kualitas telur maka terjadinya penurunan kandungan kolesterol kuning telur puyuh seiring dengan peningkatan level penggunaan produk ASATF dalam ransum. Pada perlakuan pemberian $12 \%$ ASATF dalam ransum mampu menurunkan kandungan kolesterol telur puyuh sebanyak $39,09 \%$ dari 264,75 $\mathrm{mg} / 100 \mathrm{~g}$ menjadi $158,50 \mathrm{mg} / 100 \mathrm{~g}$. Hal ini disebabkan semakin banyak digunakan produk ASATF dalam ransum maka kandungan $\beta$ karoten ransum semakin meningkat yaitu pada perlakuan $12 \%$ ASATF terdapat kandungan $\beta$ karoten ransum sebanyak $53,48 \mathrm{mg} / \mathrm{kg}$. Peningkatan kandungan $\beta$ karoten dalam ransum ini mengakibatkan jumlah $\beta$ karoten yang dikonsumsi juga meningkat. Semakin banyak jumlah $\beta$ karoten yang dikonsumsi maka semakin menurun kandungan kolesterol pada telur. Ini disebabkan $\beta$ 
karoten dapat menghambat kerja enzim HMG-KoA reduktase (Hydroksimetyl glutaryl-KoA) yang berperan dalam pembentukan mevalonat pada proses biosintesis kolesterol (Stocker, 1993).

\section{Warna Kuning Telur}

Dari Tabel 2 terlihat bahwa semakin tinggi pemakaian produk ASATF maka semakin tinggi skori warna kuning telur. Tingginya skor warna kuning telur (kuning orange) pada perlakuan pemberian $12 \%$ ASATF dalam ransum dibandingkan perlakuan kontrol disebabkan kandungan $\beta$ karoten yang tinggi pada perlakuan tersebut. Semakin tinggi penggunaan produk ASATF dapat mengurangi penggunaan jagung dan bungkil kedelai dalam ransum, maka kandungan $\beta$ karoten semakin meningkat karena produk ASATF mengandung $\beta$ karoten yang tinggi yaitu $270,60 \mathrm{mg} / \mathrm{kg}$, lebih tinggi dari pada $\beta$ karoten jagung $(33,00 \mathrm{mg} / \mathrm{kg})$ dan bungkil kedelai $(25,06$ $\mathrm{mg} / \mathrm{kg}$ ) sehingga intensitas warna kuning telur yang dihasilkan lebih tinggi (warna kuning orange) pada perlakuan pemberian $12 \%$ ASATF dalam ransum. Menurut Hausman dan Sandman (2000) bahwa $\beta$ karoten merupakan senyawa golongan karotenoid yang tidak stabil karena mudah teroksidasi menjadi xantophyll. Xanthophyl berfungsi untuk pewarnaan kuning telur. Xanthophyl tidak bisa disintesis oleh tubuh ayam, oleh karena itu xanthophyl diperoleh dari ransum yang terdiri dari bahan pakan yang mengandung xanthopyl. Pakan ternak yang merupakan sumber xanthophyl adalah jagung dan hijauan. Unggas mengkonsumsi ransum yang mengandung karotenoid lebih tinggi akan menghasilkan telur dengan intensitas warna kuning telur yang lebih tinggi pula (Udedibie dan Opara, 1998). Rataan warna kuning telur yang diperoleh dengan penggunaan $12 \%$ produk ASATF dalam ransum adalah 11,25 (terjadi peningkatan skor warna kuning telur sebesar 27,77\%). Nilai ini berada dalam kisaran warna kuning telur yang disukai konsumen menurut Udedibie and Opara (1998) yaitu 9
- 12 dan lebih tinggi dari hasil penelitian Nuraini et al. (2005) yang mendapatkan warna kuning telur 9,88 dengan penggunaan ampas sagu dan eceng gondok fermentasi dengan Trichoderma harzianum dan Nuraini dkk. (2008) menggunakan produk onggok dan ampas tahu fermentasi dengan Neurospora crassa dalam ransum ayam ras dengan warna kuning telur 10,60.

\section{KESIMPULAN}

Peningkatan penggunaan produk ampas sagu dan ampas tahu fermentasi dengan Neurospora crassa (ASATF) dalam ransum sampai $12 \%$ dapat mempertahankan penampilan produksi puyuh petelur dan dapat meningkatkan kualitas telur puyuh. Pada pemberian ASATF sampai 12\% dapat menurunkan kolesterol telur puyuh sebanyak $39,09 \%$ dan meningkatkan skor warna kuning telur sebesar $27,77 \%$.

\section{DAFTAR PUSTAKA}

Lerch. 1978. Amino acid sequence of tyrosinase from Neurospora crassa. Proc Natl Acad Sci USA. 75(8): 3635-3639.

Hausmann, A and G. Sandmann. 2000. A single five-step desaturase is involved in the carotenoid biosynthesis pathway to beta-carotene and torulene in Neurospora crassa. J.Genet.Biol.30(2):147-53.

Kashavarz,K. 2003. Effects of reducing dietary protein, methionine, choline, folic acid, and vitamin B12 during the late stages of the egg production cycle on erformance and eggshell quality. Poult Sci. 82:1407-1414.

Marathe, S., Y.G. Yu, G.E. Turner, C. Palmier and R.L. Weiss. 1998. Multiple forms of arginine and metionine from single locus in Neurospora crassa. J. Biol Chem. 273 : 29776-29785 
Murugesan, G.S., M. Sathishkumar, K. Swarninathan. 2005. Suplementation of waste tea fungal biomass as a dietary ingredien for broiler chicken. Bioresource Technology 96: 17431748.

Nuraini, Y.Rizal, H. Abbas, Sabrina dan E. Martinelly. 2005. Respon ayam buras terhadap ransum yang mengandung campuran ampas sagu dan eceng gondok yang difermentasi dengan Trichoderma harzianum. Jurnal Ilmiah Ilmu- Ilmu Peternakan Jambi VIII(3): 36-40

Nuraini dan Y. Marlida. 2005. Isolasi dan identifikasi kapang karotenogenik untuk memproduksi pakan sumber $\beta$ karoten. Laporan Penelitian Semi Que. Fakultas Peternakan Universitas Andalas Padang.

Nuraini, 2006. Potensi Kapang Neurospora crassa dalam memproduksi pakan kaya $\beta$ karoten dan pengaruhnya terhadap ayam pedaging dan petelur. Disertasi Program Pasca Sarjana Universitas Andalas, Padang.

Nuraini, Sabrina dan S.A. Latif. 2008. Performa ayam dan kualitas telur dengan penggunaan ransum mengandung onggok fermentasi dengan Neurospora crassa. Jurnal Media Peternakan Vol 31(3): 195-202

Safaa HM, Serrano MP, Valencia DG, Arbe $\mathrm{X}$, Jiménez- Moreno $\mathrm{E}$, Lázaro R, Mateos GG. 2008. Effects of the levels of methionine, linoleic Acid, and added fat in the diet on productive performance and egg quality of brown laying hens in the late phase of production. Poult Sci. 87 (8):1595-602.

Sathishkumar,A. and R. Prabakaran. 2008. Recycling of Japanese quail hatchery waste on egg production performance of quail breeders. J.Veterinary \& Anim Sci. 4(4):123128.

Standar Nasional Indonesia. 2006. Ransum puyuh petelur (quail layer). Dewan standarisasi nasional LIPI, Jakarta.

Steel, R.G.D. and J. H. Torrie. 1980. Principles and Procedures of Statistics. A. Biometrical Approach. International Student End Mc Graw Hill. Kogakusha Limited. Tokyo.

Stocker, R. 1993. Natural antioxidants and atherosclerosis. Asia Pacific Journal of Clinical Nutrition. 2 : 1520

Soares, R., Fonseca JB, Santos AS dan Mercandante. 2003. Protein requirement of Japanese quail (Coturnix coturnix japonica) during rearing and laying periods. Rev. Bras. Cienc. Avic. vol.5 no.2.

Udedibie, A. B. I. and C. C. Opara. 1998 . Responses of growing broilers and laying hens to the dietary inclusion of leaf meal from Alchornia cordifolia. Anim Feed Science and Tech. 71: 157-164 